\title{
A comparative study of serum uric acid, glucose, calcium and magnesium in eclampsia and normal pregnancy
}

\author{
Dhungana Arun ${ }^{1}$, Bharati Aakriti ${ }^{2}$, Manandhar Rosina ${ }^{3}$, Karki Chanda ${ }^{3}$ \\ ${ }^{I}$ Department of Biochemistry, Kathmandu Medical college, Kathmandu, Nepal \\ ${ }^{2}$ Department of Obstetrics and Gynaecology, Kathmandu Medical college, Kathmandu, Nepal \\ ${ }^{3}$ Department of Obstetrics and Gynaecology, Kathmandu Medical college, Nepal
}

\section{Keywords: \\ Calcium; \\ Glucose; \\ Magnesium; \\ Preclampsia; \\ Pregnancy; \\ Total protein; \\ Uric acid}

\begin{abstract}
Background: Preclampsia is associated with liver function abnormalities and renal function impairment. The objective of this study is to compare serum uric acid, glucose, calcium and magnesium in preclampsia with normal pregnancy.
\end{abstract}

Materials and methods: Normal pregnant women and pre eclamptic women of age group 20-40 years were included. Serum magnesium, calcium, glucose, uric acid were analyzed.

Results: Mean serum magnesium level in preclampsia $(1.83 \pm 0.21 \mathrm{mg} / \mathrm{dl})$ was lesser in comparison to normal pregnant women $(2.03 \pm 0.16 \mathrm{mg} / \mathrm{dl})$. Serum calcium level was lower $(8.10 \pm 0.56 \mathrm{mg} / \mathrm{dl})$ than control $(9.59 \pm 0.62 \mathrm{mg} / \mathrm{dl})$ with $\mathrm{p}<0.001$. Uric acid, glucose and lactate dehydrogenase in preclamptic women was significantly higher than that in normal pregnant women $(6.14 \pm 0.85$ vs.4.01 \pm 0.62 , $\mathrm{p}=<0.001),(94.17 \pm 18.65$ vs.86.34 $\pm 10.19, \mathrm{p}=0.033)$ and $(466.80 \pm 97.29$ vs. $194.22 \pm 39.76, \mathrm{p}=<0.001)$ respectively.

Conclusion: There were significant changes in serum magnesium, uric acid, calcium, glucose, lactate dehydrogenase and total protein in pregnant women.

\section{Correspondence:}

Dr. Arun Dhungana, MD

Lecturer, Department of Biochemistry

Kathmandu Medical College Teaching Hospital, Kathmandu, Nepal

ORCID ID: 0000-0003-2083-649X

E-mail : a_dhungana1@yahoo.com
Citation: Dhungana A, Bharati A, Manandhar R, Karki C. A comparative study of serum uric acid, glucose, calcium and magnesium in pre-eclampsia and normal pregnancy. J Pathol Nep. 2017;17:115561 doi: $10.3126 /$ jpn.v7i2.17995

Copyright: This is an open-access article distributed under the terms of the Creative Commons Attribution 4.0 International License, which permits unrestricted use, distribution, and reproduction in any medium, provided the original author and source are credited.

\section{INTRODUCTION}

Preclampsia, a systemic syndrome of pregnancy is clinically characterized by new onset of proteinuria and hypertension after 20 week of gestation and is associated with significant morbidity and mortality to both mothers and fetuses. Preclampsia originates in the placenta, starting with inadequate cytotrophoblast invasion of the spiral arteries, leading to maladaptation of maternal spiral arterioles, which may be associated with an increased vascular resistance of the uterine artery and a decreased perfusion of the placenta. ${ }^{1,2}$ In developing countries where access to health care is limited, preclampsia is a leading cause of maternal mortality, with estimates of $>60,000$ maternal deaths $/ y{ }^{3}{ }^{3}$ In the developed world, the burden of this disease falls on the neonate because of premature deliveries performed to 
preserve the health of the mother. Worldwide, preclampsia is associated with a perinatal and neonatal mortality rate of $10 \%{ }^{4}$ Its incidence is in $4-8 \%$ of pregnancies. ${ }^{1}$ Interestingly, the significant reduction in serum calcium and magnesium are found in preclamptic mothers. ${ }^{5}$ On the physiological basis, calcium plays an important role in muscle contraction and regulation of water balance in cells. A change in plasma calcium concentration leads to the alteration of blood pressure. ${ }^{6,7}$ Elevated intracellular calcium levels are due to decreased calcium- dependent ATPase activity, as calcium uptake by red blood cells at 30 min was similar in preclamptic and normotensive gravid women. Hypocalciuria in Pregnancy Induced Hypertension (PIH) might be a result of abnormal calcium uptake and decreased calcium efflux by the renal tubular cells similar to that of RBCs. ${ }^{7}$ The decreased serum calcium and the increased intracellular calcium can cause an elevation of blood pressure in preclamptic mothers. ${ }^{6,7} \mathrm{PIH}$ is associated with abnormal calcium metabolism. Generally, magnesium has been known as an essential cofactor for many enzyme systems. Magnesium sulfate appears to be safe and effective for the prevention of seizures. ${ }^{1,8}$ Hyperuricemia is believed to result from the decreased renal excretion that occurs as a consequence of the preclampsia. Hyperuricemia induces endothelial dysfunction and may induce hypertension and vascular disease. Therefore, the modification of calcium, magnesium and uric acid metabolism during pregnancy could be one of the potential causes of preclampsia. ${ }^{1,5,9-11}$ Studies to establish a direct cause-and-effect relationship between hyperuricemia and endothelial and vascular dysfunction in preclampsia are urgently needed. ${ }^{9}$ However, the exact etiology of preclampsia is still unknown. The results from many clinical studies show the relationship between the aggravation of the hypertensive complication and the change in concentration of various chemistries in mother's serum. ${ }^{1,6}$ The development of preclampsia in patients with gestational diabetes mellitus has been reported. ${ }^{12}$ In preclamptic women, plasma insulin fasting insulin resistance Index (FIRI), calculated from fasting insulin and glucose concentration have been found significantly higher than the baseline value from 20 and 24 weeks respectively. ${ }^{13}$ In gestational diabetes mellitus (GDM) patients having higher blood pressure readings early in pregnancy, even prior to GDM diagnosis, were associated with the subsequent development of preclampsia. ${ }^{12}$ Hypocalcemia, hypomagnesaemia and hyperuricemia seen in serum need to be correlated for sever preclampsia. ${ }^{14,15}$ Interestingly, variable serum calcium, magnesium and uric acid are found in preclamptic mothers. . $^{1,16 .}$

\section{MATERIAL AND METHODS}

The present case control study was carried out at Kathmandu medical college from July 2015 to July 2016. In the present study group $\mathrm{I}=35$ normal pregnant woman and group $\mathrm{II}=35$ Preclamptic woman (mild and severe) of age group 20-40 years attending outpatient and inpatient department were included.

A written consent was taken from the patients to participate in this study and ethical clearance approval was obtained from institutional review committee (IRC). Blood sample was taken from all the participants by venipuncture from cubital vein and sample was collected in a vial under aseptic condition. The serum magnesium level was estimated with semi-auto analyzer whereas, the levels of serum calcium, glucose, uric acid and other different parameters were estimated with Selectra pro S auto analyzer using Elitech reagents in both the cases and controls. An increased activity of serum magnesium have been found in cases of renal failure, dehydration, severe diabetic acidosis and Addison's disease, however, the decreased serum magnesium levels have been observed in cases of diabetes, alcoholism, hyperthyroidism, hypoparathyroidism, myocardial infarction, congestive heart failure and liver cirrhosis. ${ }^{17}$ So, patient with these cases were excluded from the study. The sample size was calculated from the study of Sukonpan $\mathrm{K}$ et al. ${ }^{5}$ It was computed using following information mean $=0.85$ and standard deviation $=0.09$ for normal control and mean $=0.77$ and standard deviation $=0.08$ for preclampsia with power of test $\beta=0.8 \%$ and level of significance $\beta=5 \%$. So the calculated sample size was 18 cases/group for magnesium and for calcium mean $=9.7$ and standard deviation $=0.7$ for normal control and mean $=9.0$ and standard deviation $=0.4$ for preclampsia with power of test $\beta=0.8 \%$ and level of significance $\beta=5 \%$. So the calculated sample size was 11 cases/group. So, for this study group I=35 and group II 35 cases was enrolled.

\section{Principle $^{17}$}

\section{Xylidyl Blue Colorimetric Method}

In an alkaline medium, the magnesium ions of the sample will produce a colored complex with xylidyl blue. Colour intensity is directly proportional to the magnesium ions' concentration present in the sample. GlycoletherdiamineN'N'N'N'-tetraacetic acid (GEDTA) perform as a chelating agents

Normal serum magnesium level -1.9-2.5mg/dL

\section{PAP Enzymatic Colorimetric Method}

Determination of uric acid by reaction with uricase. The formed $\mathrm{H}_{2} \mathrm{O}_{2}$ reacts under catalysis of peroxidase with 3 , 5-dichloro-2hydroxybenzene-sulfonic acid (DCHBS) and 4-aminophenazone (PAP) to give a red-violet quinoneimine dye as indicator.

Uric acid $+\mathrm{O}_{2}+\mathrm{H}_{2} \mathrm{O} \underset{\text { Uricase }}{\longrightarrow}$ allantoin $+\mathrm{CO}_{2}+\mathrm{H}_{2} \mathrm{O}_{2}$ 
Table 1: Comparison of the clinical characteristics for group of participants

\begin{tabular}{|c|c|c|c|c|c|}
\hline S. No & \multicolumn{2}{|c|}{ Normal pregnancy $(n=35)$} & \multicolumn{2}{|c|}{ Preclampsia $(n=35)$} & p value \\
\hline Age( years) & \multicolumn{2}{|c|}{$27.08 \pm 4.06$} & \multicolumn{2}{|c|}{$33.33 \%$} & 0.66 \\
\hline Nulliparous & \multicolumn{2}{|c|}{$25(71.4 \%)$} & \multicolumn{2}{|c|}{$12.63 \%$} & \\
\hline Multiparous & \multicolumn{2}{|c|}{$10(28.6 \%)$} & \multicolumn{2}{|c|}{$4.60 \%$} & \\
\hline Gestational age & \multicolumn{2}{|c|}{$37.40 \pm 1.11$} & \multicolumn{2}{|c|}{$2.30 \%$} & $<0.001$ \\
\hline Systolic Blood pressure & \multicolumn{2}{|c|}{$108.28 \pm 10.14$} & \multicolumn{2}{|c|}{$2.30 \%$} & $<0.001$ \\
\hline Diastolic Blood pressure & \multicolumn{2}{|c|}{$70 \pm 7.17$} & \multicolumn{2}{|c|}{$1.15 \%$} & $<0.001$ \\
\hline Symptoms & Yes & No & Yes & No & \\
\hline Headache & $9(25.7 \%)$ & $26(74.3 \%)$ & $21(60 \%)$ & $14(40 \%)$ & \\
\hline Swelling in face and hand & $16(45.7 \%)$ & $19(54.3 \%)$ & $25(71.4 \%)$ & $10(28.6 \%)$ & \\
\hline Nausea and vomiting & - & $35(100 \%)$ & $3(8.6 \%)$ & $32(91.4 \%)$ & \\
\hline Vision problem & - & $35(100 \%)$ & - & $35(100 \%)$ & \\
\hline Seizure & - & $35(100 \%)$ & $5(14.3 \%)$ & $25(85.7 \%)$ & \\
\hline
\end{tabular}

Table 2: Comparison of serum magnesium, uric acid, calcium and glucose for different groups

\begin{tabular}{|c|c|c|c|c|}
\hline Parameter (Sr.) & Diagnosis & No. of patients & Mean \pm S. D & P Value \\
\hline \multirow{2}{*}{ Magnesium } & Preclampsia & \multirow{2}{*}{35} & $1.83 \pm 0.21$ & \multirow{2}{*}{$<0.001$} \\
\hline & Control & & $2.03 \pm 0.16$ & \\
\hline \multirow{2}{*}{ Uric acid } & Preclampsia & \multirow{2}{*}{35} & $6.14 \pm 0.85$ & \multirow{2}{*}{$<0.001$} \\
\hline & Control & & $4.01 \pm 0.62$ & \\
\hline \multirow{2}{*}{ Calcium } & Preclampsia & \multirow{2}{*}{35} & $8.10 \pm 0.56$ & \multirow{2}{*}{$<0.001$} \\
\hline & Control & & $9.59 \pm 0.62$ & \\
\hline \multirow{2}{*}{ Glucose } & Preclampsia & \multirow{2}{*}{35} & $94.17 \pm 18.65$ & \multirow{2}{*}{$<0.033$} \\
\hline & Control & & $86.34 \pm 10.19$ & \\
\hline
\end{tabular}
$\underset{4 \mathrm{H}_{2} \mathrm{O}}{2 \mathrm{H}_{2} \mathrm{O}_{2}}+$ DCHBS + PAP $\underset{\text { Peroxidase }}{\longrightarrow}$ quinoneimine $+\mathrm{HCl}+$

\section{Photometric test by CPC method}

Calcium ions react with o-cresolphthalein-complexone (CPC) in an alkaline medium to form a purple colored complex. The absorbance of this complex is proportional to the calcium concentration in the sample.

\section{GOD-POD Enzymatic Colorimetric Method}

The glucose is determined after enzymatic oxidation in the presence of glucose oxidase (GOD). The formed hydrogen peroxide reacts under catalysis of peroxidase (POD) with phenol and 4-aminophenazone to a red-violet quinoemine dye as indicator

\section{Reaction principle}

Glucose $+\mathrm{O}_{2}+\mathrm{H}_{2} \mathrm{O} \underset{\text { GOD }}{\longrightarrow}$ gluconic acid $+\mathrm{H}_{2} \mathrm{O}_{2}$

$2 \mathrm{H}_{2} \mathrm{O}_{2}+4$-aminophenazone + phenol $\underset{\text { POD }}{\longrightarrow}$ quinoemine $+4 \mathrm{H}_{2} \mathrm{O}$

\section{Statistical analysis}

Statistical analysis was done by SPSS (Statistical package for social science) version 15 . Independent sample t-test was used to compare the means between different groups.

\section{RESULTS}

Comparison of the clinical characteristics and symptoms for group of participants are shown in the Table 1. 60\% of the case in preclampsia was nulliparous with period of gestation 35.91 week. About $60 \%(\mathrm{n}=21)$ of the patient complain regarding headache. $71.4 \%(\mathrm{n}=25)$ present with swelling in face and hand. $8.6 \%(n=3)$ of them have nausea and vomiting and $14.3 \%$ have an episode of seizure. The mean systolic blood pressure recorded in preclampsia was $144 \pm 11.93$ which was statistically significant $(\mathrm{p}<0.001)$ when compared with control $(108.28 \pm 10.14)$ and mean diastolic blood pressure recorded in preclampsia was 89 \pm 5.25 which was statistically significant $(\mathrm{p}<0.001)$ when compared with control $(70 \pm 7.17)$.

In this study, the mean serum magnesium level of preclampsia $(1.83 \pm 0.21 \mathrm{mg} / \mathrm{dl})$ was lesser in comparison to normal pregnant women $(2.03 \pm 0.16 \mathrm{mg} / \mathrm{dl})$. Similarly 
Table 3: Comparison of other biochemical parameter for different group

\begin{tabular}{|c|c|c|c|c|}
\hline Parameter (Sr.) & Diagnosis & No. of patients $(n=35)$ & Mean \pm S. D & P Value \\
\hline \multirow{2}{*}{ Protein } & Preclampsia & \multirow{2}{*}{35} & $5.51 \pm 0.46$ & \multirow{2}{*}{$<0.001$} \\
\hline & Control & & $7.08 \pm 0.37$ & \\
\hline \multirow{2}{*}{ Creatinine } & Preclampsia & \multirow{2}{*}{35} & $0.72 \pm 0.13$ & \multirow{2}{*}{$<0.001$} \\
\hline & Control & & $0.59 \pm 0.12$ & \\
\hline \multirow{2}{*}{ Urea } & Preclampsia & \multirow{2}{*}{35} & $30.05 \pm 6.22$ & \multirow{2}{*}{0.002} \\
\hline & Control & & $25.65 \pm 5.04$ & \\
\hline \multirow{2}{*}{ AST } & Preclampsia & \multirow{2}{*}{35} & $85.42 \pm 50.35$ & \multirow{2}{*}{$<0.001$} \\
\hline & Control & & $29.31 \pm 5.08$ & \\
\hline \multirow{2}{*}{ ALT } & Preclampsia & \multirow{2}{*}{35} & $65.40 \pm 28.62$ & \multirow{2}{*}{$<0.001$} \\
\hline & Control & & $27.64 \pm 6.41$ & \\
\hline \multirow{2}{*}{ GGT } & Preclampsia & \multirow{2}{*}{35} & $32.77 \pm 6.58$ & \multirow{2}{*}{0.365} \\
\hline & Control & & $31.46 \pm 5.38$ & \\
\hline \multirow{2}{*}{ LDH } & Preclampsia & \multirow{2}{*}{35} & $466.80 \pm 97.29$ & \multirow{2}{*}{$<0.001$} \\
\hline & Control & & $194.22 \pm 39.76$ & \\
\hline \multirow{2}{*}{ ALP } & Preclampsia & \multirow{2}{*}{35} & $449.82 \pm 159.56$ & \multirow{2}{*}{0.577} \\
\hline & Control & & $430.02 \pm 135.32$ & \\
\hline \multirow{2}{*}{ Sodium } & Preclampsia & \multirow{2}{*}{35} & $142.11 \pm 1.87$ & \multirow{2}{*}{$<0.001$} \\
\hline & Control & & $139.31 \pm 2.3$ & \\
\hline \multirow{2}{*}{ Potassium } & Preclampsia & \multirow{2}{*}{35} & $3.84 \pm 0.37$ & \multirow{2}{*}{0.599} \\
\hline & Control & & $3.89 \pm 0.39$ & \\
\hline \multirow{2}{*}{ Total Bilirubin } & Preclampsia & \multirow{2}{*}{35} & $0.66 \pm 0.18$ & \multirow{2}{*}{0.364} \\
\hline & Control & & $0.62 \pm 0.17$ & \\
\hline \multirow{2}{*}{ Direct Bilirubin } & Preclampsia & 25 & $0.22 \pm 0.10$ & 0002 \\
\hline & Control & 35 & $0.16 \pm 0.17$ & 0.003 \\
\hline
\end{tabular}

the level of serum calcium level was lower $(8.10 \pm 0.56 \mathrm{mg} /$ dl) when it was compared with control $(9.59 \pm 0.62 \mathrm{mg} /$ dl). (Table 2) The difference in the mean was statistically significant $(\mathrm{p}<0.001)$. In the present study serum total protein level were lower in preclamptic women $(5.51 \pm$ $0.46)$ when compared with normal pregnant women $(7.08 \pm$ 0.37 ) as, shown in Table 3 which was statistically significant $\mathrm{p}<0.001$.

\section{DISCUSSION}

In the present study 35 normal pregnant women and 35 case suffering from preclampsia (mild and sever) are enrolled. In our study, the mean serum magnesium level of preclampsia $(1.83 \pm 0.21 \mathrm{mg} / \mathrm{dl})$ was lesser in comparison to normal pregnant women $(2.03 \pm 0.16 \mathrm{mg} / \mathrm{dl})$. Similarly the level of serum calcium level was lower $(8.10 \pm 0.56 \mathrm{mg} / \mathrm{dl})$ when it was compared with control $(9.59 \pm 0.62 \mathrm{mg} / \mathrm{dl})$. Serum calcium and magnesium are two intracellular ions that are very important for cellular metabolism such as muscles contractibility, secretion, neuronal activities as well as cellular death. Decrease level of two intracellular ions are the risk factor for preclampsia has been hypothesized. ${ }^{18}$ The difference in the mean was statistically significant $(\mathrm{p}<0.001)$ as shown in Table 2. The level of magnesium was decreased in preclampsia. Similar finding were reported by Sukonpan $\mathrm{K}$ et $\mathrm{al}^{5}$, Sandip $\mathrm{S}$ et $\mathrm{al}^{14}$ and Mittal $\mathrm{S}$ et al. ${ }^{19}$ Magnesium is essential cofactor for the various enzymes and it plays an important role in neurochemical transmission and peripheral vasodilation. ${ }^{19}$ It appears to trigger the release of prostacyclin, a potent vasodilator and inhibitor of platelet aggregation, which is synthesized by the endothelium of vessels. The hypomagnesaemia in most pregnant women is associated with hemodilution, renal clearance during pregnancy and consumption of minerals by growing foetus. ${ }^{5,14,15,19}$ Magnesium levels may have significant effects on cardiac excitability and on vascular tone, contractility and reactivity. The consequences of low magnesium may lead to a reduction in cerebral blood flow, cerebral vasospasm and increase in neuronal burst. ${ }^{14,20}$ Macdonald et al have shown experimentally that magnesium has a vasoprotective effect. ${ }^{21}$ This explains the use of magnesium sulphate as a neuroprotectant and antivasospastic agent. ${ }^{14}$

In Table 2, the serum calcium level in preclamptic pregnant women $(8.10 \pm 0.56 \mathrm{mg} / \mathrm{dl})$ was significantly lower than normal pregnant women $(9.59 \pm 0.62 \mathrm{mg} / \mathrm{dl})$. When calcium intake is low it stimulates Parathyroid hormone (PTH) production, which increases the intracellular calcium level, therefore, the effect of serum calcium and its correlation with change in blood pressure could be explained by the level of intracellular concentration of calcium. When serum calcium concentration is decreased; intracellular 


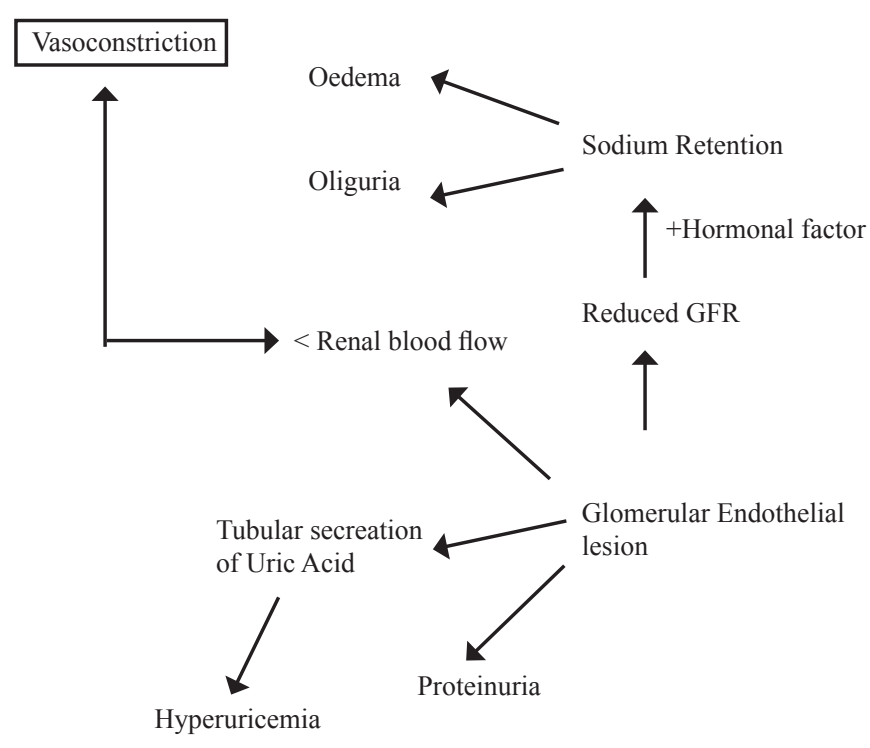

Figure 1: Consequences of renal lesion in preclampsia

calcium concentration will be increased; which leads to the constriction of smooth muscles in blood vessels and also increases in vascular resistance. ${ }^{19,22}$ Similar findings were obtained by Sandip $\mathrm{S}$ et $\mathrm{al}^{14}$,Sukonpan $\mathrm{K}$ et $\mathrm{al}^{5}$ and Kister $\mathrm{K}$ et $\mathrm{al} .{ }^{6}$ In the present study serum uric acid level were also raised in preclamptic women $(6.14 \pm 0.85 \mathrm{mg} / \mathrm{dl})$ when compared with normal pregnant woman $(4.01 \pm 0.62 \mathrm{mg} / \mathrm{dl})$ as, shown in the Table 2 which was statistically significant $\mathrm{p}<0.001$.Uric acid is filtered by the renal glomeruli, absorbed by the first part of the proximal convoluted tubule, with a further secretion and reabsorption phase. Ten percent of the filtered uric acid is excreted in the urine. During pregnancy, uric acid clearance increases from 6 to $12 \mathrm{~mL} / \mathrm{min}$ to 12 to $20 \mathrm{~mL} / \mathrm{min}$, with a $25 \%$ decrease in blood concentration. ${ }^{23}$ Elevated serum uric acid level due to decreased renal urate excretion is frequently found in women with preclampsia. ${ }^{14}$ Recently, increased oxidative stress and formation of reactive oxygen species (ROS) have been proposed as another contributing source of hyperuricemia in preclampsia apart from renal dysfunction. ${ }^{24}$ Uric acid (as also creatinine and to some extent urea), possesses water soluble or hydrophilic antioxidant characteristics, may delay or inhibit cellular damage mainly through the free radical scavenging property; it also presents strong antioxidant activity towards ROS in aqueous phase. ${ }^{25}$ Uric Acid contributes to about $60 \%$ of free radical scavenging activity in human serum. ${ }^{26}$ The observed uric acid elevation may be a protective response, capable of opposing harmful effects of free radical activity and oxidative stress. Elevated serum uric acid concentrations predict the development of hypertension. ${ }^{24}$ Soluble uric acid impairs nitric oxide generation in endothelial cells thus inhibit vascular relaxation. Hence, hyperuricemia can induce endothelial dysfunction (impaired endothelial integrity). ${ }^{14,24}$ Similar type of finding were also reported by Lam C et $\mathrm{al}^{27}$, Manjareeka $\mathrm{M}$ et $\mathrm{al}^{24}$ and Sandip $\mathrm{S}$ et $\mathrm{al}^{14}$ It has been proposed that these pregnancy mediated changes in serum uric acid are often the result of altered renal handling. ${ }^{24}$ In the present study serum total protein level were lower in preclamptic women $(5.51 \pm 0.46)$ when compared with normal pregnant women $(7.08 \pm 0.37)$ as, shown in Table 3 which was statistically significant $\mathrm{p}<0.001$. Similar type of finding was also reported by Sunitha T et al. ${ }^{28}$

In the present study the mean blood glucose level of normal pregnant women $(86.34 \pm 10.19 \mathrm{mg} / \mathrm{dl})$ was lesser in comparison to preclampatic women $(94.17 \pm 18.65 \mathrm{mg} /$ dl). Tumor Necrosis factor- alpha (TNF- $\alpha$ ) as cytokine playing role in raising blood sugar especially in preclampsia patients have been hypothesized. ${ }^{29}$ Other biochemical parameters were also evaluated among that level of serum Lactate dehydrogenase (LDH) was significantly higher in preclamptic women $(466.80 \pm 97.29 \mathrm{mg} / \mathrm{dl})$ when compared to normal pregnant women $(194.22 \pm 39.76 \mathrm{mg} / \mathrm{dl})$. The difference in the mean was statistically significant as $\mathrm{p}<0.001$ as shown in Table 3. Lactate dehydrogenase is an intracellular enzyme and its level is increased in preclamptic women due to cellular death. So, serum LDH levels can be used to assess the extent of cellular death and thereby the severity of disease in this group of women. Evaluation of LDH level during preclampsia can be useful in making decision, regarding the management strategies to improve the maternal and fetal outcome. ${ }^{30}$ Similar type of finding was obtained by Jaiswar S P et al. ${ }^{30}$

Limitation: The effect of supplementation of Magnessium to the patient can be done for evaluation of preclampsia is a part of further research.

\section{CONCLUSION}

Preclampsia is one of the major challenges for the obstetrician, as it may results into multi-organ dysfunction. It is commonly seen in nulliparous women and is associated with liver function abnormalities and renal function impairment which is characterized by endothelial cell injury. The complications associated with it are enormous and its consequences faced by mother and neonates need to be minimized. Our present study shows the significant changes in various biochemical parameters like serum magnesium, uric acid, calcium, glucose, $\mathrm{LDH}$, total protein and different other parameter in pregnant women with significant increase in systolic and diastolic blood pressures which could confirm the severity that is associated with it. It may be noteworthy in understanding the pathological process of preclampsia. So, effective strategies need to be developed and applied for the prevention of preclampsia. Regarding the role of magnesium supplement, there was no strong evidence that clearly shows the therapeutic effect of magnesium in preclampsia prophylaxis. However, due to the properties of vasodilatation and uterine relaxation of 
magnesium, a magnesium-rich diet as well as magnesium supplement should be an advantage to preclamptic pregnant women in prevention of the aggravation of hypertension. The actual role of magnesium and calcium supplementation for the prevention of preclampsia must be further investigated.

\section{ACKNOWLEDGMENT}

We would like to thank Prof. Dr Rachana Shah for the support during the research period. We also would like to thank Institutional review committee, patient and nursing team, especial thanks to Asst. Prof. Mr. Arun pandeya, Lecturer Mr. Naveen Shreevastva, laboratory staff, Mr. Hari Sharan Makaju and entire biochemistry supporting staff for the great help and support during the episode of the study.

\section{Conflict of interest: None}

\section{REFERENCES}

1. Walker JJ. Pre-eclampsia. Lancet. 2000;356:1260-5. Crossref

2. Wang A, Rana S, Karumanchi SA. Preeclampsia: the role of angiogenic factors in its pathogenesis. Physiology (Bethesda). 2009;24:147-58. Crossref

3. World Health Organization. World Health Report: Make Every Mother, and Child Count. Geneva:2005.

4. Altman D, Carroli G, Duley L, Farrell B, Moodley J, Neilson J, et al. Do women with pre-eclampsia, and their babies, benefit from magnesium sulphate? The Magpie Trial: a randomised placebocontrolled trial. Lancet. 2002;359:1877-90. Crossref

5. Sukonpan K, Phupong V. Serum calcium and serum magnesium in normal and preeclamptic pregnancy. Arch Gynecol Obstet. 2005;273:12-6. Crossref

6. Kisters K, Barenbrock M, Louwen F, Hausberg M, Rahn KH, Kosch M. Membrane, intracellular, and plasma magnesium and calcium concentrations in preeclampsia. Am J Hypertens. 2000;13:765-9. Crossref

7. Ray J, Vasishta K, Kaur S, Majumdar S, Sawhney H. Calcium metabolism in pre-eclampsia. Int J Gynaecol Obstet. 1999;66:24550. Crossref

8. Singh J, O'Donovan M, Coulter-Smith SD, Geary M. An audit of the use of magnesium sulphate in severe pre-eclampsia and eclampsia. J Obstet Gynaecol. 2005;25:15-7. Crossref

9. Kang DH, Finch J, Nakagawa T,et al. Uric acid, endothelial dysfunction and pre-eclampsia: searching for a pathogenetic link. J Hypertens. 2004;22:229-35. Crossref

10. Khosla UM, Zharikov S, Finch JL, et al. Hyperuricemia induces endothelial dysfunction. Kidney Int. 2005;67:1739-42. Crossref
11. Chappell LC, Seed PT, Briley A, et al. A longitudinal study of biochemical variables in women at risk of preeclampsia. Am J Obstet Gynecol. 2002;187:127-36. Crossref

12. Yogev Y, Langer O, Brustman L, Rosenn B. Pre-eclampsia and gestational diabetes mellitus: does a correlation exist early in pregnancy? J Matern Fetal Neonatal Med. 2004;15:39-43. Crossref

13. Anim-Nyame N, Sooranna SR, Jones J, Alaghband-Zadeh J, Steer PJ, Johnson MR. Insulin resistance and pre-eclampsia: a role for tumor necrosis factor-alpha? Gynecol Endocrinol. 2004;18:117-23. Crossref

14. Sendhav S, Khubchandani A, Gandhi P, Sanghani H, Sidhu G, Vadhel A. A Comparative Study Of Serum Uric Acid, Calcium and Magnesium In Preeclampsia and Normal Pregnancy. JARBS. $2013 ; 5: 55-8$

15. Punthumapol C, Kittichotpanich B. Serum calcium, magnesium and uric acid in preeclampsia and normal pregnancy. J Med Assoc Thai. 2008;91:968-73. Crossref

16. Kisters K, Korner J, Louwen F, et al. Plasma and membrane Ca2+ and $\mathrm{Mg} 2+$ concentrations in normal pregnancy and in preeclampsia. Gynecol Obstet Invest. 1998;46:158-63. Crossref

17. Burtis CA, Ashwood ER, Bruns DE. Bone and mineral metabolism. In: Risteli J, Winter WE, Kleerekoper M, Risteli L, editors. Tietz Textbook of Clinical Chemistry and Molecular Diagnostics. 5th ed. Philadelphia: Elsevier, Saunders; 2012. p. 1751-5.

18. Kosch M, Hausberg M, Louwen F, Barenbrock M, Rahn KH, Kisters $\mathrm{K}$. Alterations of plasma calcium and intracellular and membrane calcium in erythrocytes of patients with pre-eclampsia. J Hum Hypertens. 2000;14:333-6. Crossref

19. Mittal S, Shaikh MKS, Thakur R, Jain D. Comparison of serum calcium and magnesium levels between preeclamptic and normotensive healthy pregnant women. Int J Reprod Contracept Obstet Gynecol. 2014;3:959-62. Crossref

20. Geiger H, Wanner C. Magnesium in disease. Clin Kidney J. 2012;5:i25-i38. Crossref

21. Macdonald RL, Curry DJ, Aihara Y, Zhang ZD, Jahromi BS, Yassari R. Magnesium and experimental vasospasm. J Neurosurg. 2004;100:106-10. Crossref

22. Atallah AN, Hofmeyr GJ, Duley L. Calcium supplementation during pregnancy for preventing hypertensive disorders and related problems. Cochrane Database Syst Rev. 2002:CD001059. Crossref

23. Williams KP, Galerneau F. The role of serum uric acid as a prognostic indicator of the severity of maternal and fetal complications in hypertensive pregnancies. J Obstet Gynaecol Can. 2002;24:628-32. Crossref

24. Manjareeka M, Nanda S. Elevated level of serum uric acid, creatinine 
or urea in preeclamptic women. Int J Med Sci Public Health. 2013;2:43-7. Crossref

25. Ames BN, Cathcart R, Schwiers E, Hochstein P. Uric acid provides an antioxidant defense in humans against oxidant- and radicalcaused aging and cancer: a hypothesis. Proc Natl Acad Sci U S A. 1981;78:6858-62. Crossref

26. Waring WS. Antioxidants in prevention and treatment of cardiovascular disease. Proc R Coll Physicians Edinb. 2001;31:28892.

27. Lam C, Lim KH, Kang DH, Karumanchi SA. Uric acid and preeclampsia. Semin Nephrol. 2005;25:56-60. Crossref
28. Sunithaaa T, Sameera K, Umaramani G. Study of Biochemical changes in Preeclamptic Women. Int J Biol Med Res. 2012;3:2025-8.

29. Gulati R. Raised serum TNF-alpha, blood sugar and uric acid in preeclampsia in third trimester of pregnancy. Nep Med Assoc. 2005;44:36-8.

30. Jaiswar SP, Gupta A, Sachan R, Natu SN, Shaili M. Lactic dehydrogenase: a biochemical marker for preeclampsia-eclampsia. J Obstet Gynaecol India. 2011;61:645-8. Crossref 